\title{
Maternal Love and Freedom under Slavery-Deconstruction of the Female Subjectivity in Beloved
}

\author{
Songtao Xiong1 ${ }^{*}$, Yuhua Fang ${ }^{2}$ \\ ${ }^{1}$ School of Languages, Shanghai University of International Business and Economics, Shanghai, China \\ ${ }^{2}$ School of Foreign Languages, China University of Geosciences, Wuhan, China \\ Email: *xiongsongtao666@163.com
}

How to cite this paper: Xiong, S. T., \& Fang, Y. H. (2019). Maternal Love and Freedom under Slavery-Deconstruction of the Female Subjectivity in Beloved. Advances in Literary Study, 7, 155-163. https://doi.org/10.4236/als.2019.74010

Received: August 16, 2019

Accepted: September 9, 2019

Published: September 12, 2019

Copyright (อ 2019 by author(s) and Scientific Research Publishing Inc. This work is licensed under the Creative Commons Attribution International License (CC BY 4.0).

http://creativecommons.org/licenses/by/4.0/

\begin{abstract}
Toni Morrison (1931-2019) is an inspiring female writer in the American contemporary literary world. In response to the physical and spiritual trauma caused by the slavery system, Toni Morrison shows her concerns about the black female group to females of different races and ethnics. From the perspective of J. Hillis Miller's techniques of deconstruction, this paper is going to reveal the growth curves of the three heroines and explore the maternal love and freedom of the female subjectivity under slavery.
\end{abstract}

\section{Keywords}

Maternal Love, Freedom, Female Subjectivity, Deconstruction, Beloved

\section{Introduction}

Beloved, the novel was published by Toni Morrison in 1987, in which many of the characters are born into slavery and experience the imposed objectivity of its commodifying ideology (Elliott, 2000). In this novel, Sethe, the protagonist, was sold to the Garners and brought to the Sweet Home in thirteen. After the brutal treatment of Schoolteacher, Sethe tried very hard to flee away. In the process of escaping to Cincinnati, where her mother-in-law Baby Suggs lived, Sethe gave birth to her fourth child Denver. Then aided by a black man, Sethe was able to join with Baby Suggs at the house situated at 124 Bluestone Road and enjoyed twenty-eight days' freedom. On the last day, however, Schoolteacher came and attempted to recapture her and her children. Rather than surrender her children to a life of dehumanizing slavery, she killed her baby girl with a handsaw. From then on, the house was haunted by the ghost of the dead girl. It was Paul D's ar- 
rival which drove the ghost away for one time, while the ghost incarnated as a young girl and appeared in the yard again. She called herself "Beloved" and consumed Sethe's love and attention greedily. In the end, Sethe's daughter Denver called for the community's help to exorcise Beloved, which made Sethe get rid of the ghost and restore her selfhood.

The novel shows that the female subjectivity can change their state and get redemption by the awakening of maternal love and freedom no matter what oppression and trauma of the heart they are suffering under slavery. The novel has been illustrated from different angles. Linda Krumholz explored the historical recovery through analyzing Baby Suggs and rituals of healing, Beloved as the trickster of history, Sethe's healing ritual, and Denver and the history of slavery (Krumholz, 1992). Jean Wyatt discussed the maternal body in language as a discourse of presence and figured out multiple identities of Beloved (Wyatt, 1993). Mary Jane Suero Elliot thought characters in Beloved are the commodified subjectivity for the postcolonial experience in a domestic context (Elliott, 2000). These interpretations emphasize the effects of the specific historical, contextual and characters' elements on the female subjectivity under slavery.

In the viewpoint of above, the novel Beloved has been explained from different perspectives. But few explanations are based on the literary techniques. As a novel with everlasting literary and humanistic influence, Beloved still remains the huge space of interpretation because of its acquired new meanings in this era. This paper tries to analyze the growth curves of the three heroines in the novel and detects the maternal love and freedom under slavery from the perspective of J. Hillis Miller's techniques of deconstruction.

\section{Discussion}

The research of subjectivity originates from the research of human beings in the Renaissance period. From the perspective of epistemology, "subjectivity refers to human beings' being conscious of their statuses, abilities and values as the subject in the objective world." (Feng, 1992). As for the concept of "female subjectivity", Mary Wollstonecraft mentioned the importance of education and reason in the construction of selfhood of women (Wollstonecraft, 2015). Jean-Jacques Rousseau once pointed out that women were educated to be sensational, and they could make change only if they were provided with equal opportunities as men (Rousseau, 2014). Margaret Fuller called for women's self-subsistence and internal transformation (Fuller, 2002). John Mill argued that women may attain full rational self-realization once they were allowed education, partnership, as well as a coequal share and ensured with the freedom of individual choice (Mill, 1996). Therefore, female subjectivity refers to women's being conscious of their status, role and value as a subject in the objective world. And this paper focuses on the analysis of the characters serving as the female subjectivity: Baby Suggs, Sethe and Denver-the women of three generations in one family.

As a prominent American deconstructionist, J. Hillis Miller defines decon- 
struction as searching for the thread in the text in question which will unravel it all, and concludes that there are multiple layers to any text, both its clear face and its deep countervailing subtext, "On the one hand, the 'obvious and univocal reading' always contains the 'deconstructive reading' as a parasite encrypted within itself as part of itself. On the other hand, the 'deconstructive' reading can by no means free itself from the metaphysical reading it means to contest." (Miller, 2000). In Miller's deconstruction, he centers on readers' own feelings about the text, and tends to deconstruct a text through the analysis of figures of speech, etymology and imageries, which will also be used to analyze this novel.

In this paper, the growth curves of the three heroines will be discussed first. Then the techniques of deconstruction will be applied into analyzing the female subjectivity featured by the three heroines, Sethe, Baby Suggs and Denver. Next the discussion will emphasize on findings with analysis. Finally the paper will draw a conclusion to all the deductions, which reveals that the protection of the female subjectivity requires reconstructing the identity, seeking for community shelter and challenging the patriarchal society.

\section{An Analysis of the Representative Female Subjectivity}

\subsection{The Female Subjectivity of Sethe}

The black female subjectivity in this novel is oppressed not only as the black but also as women. In this novel, Sethe had two kinds of masters, one was the Garners, and another was Schoolteacher. Although they managed the slaves in different ways, their natural instincts were the same. The Garners were gentler when managing slaves for allowing Halle to earn money on the weekends to buy her mother freedom, and Mrs. Garner even gave Sethe earrings as a wedding gift. However, the Garners' paternalism and condescension are simply watereddown versions of the Schoolteacher's vicious racism. The facts behind the hypocritical benevolence were that slaves are only objects or animals owned by slave owners, and Sethe cannot hold a wedding ceremony with Halle for not being regarded as a human being in this novel. After Mr Garner's death, Schoolteacher took charge of the Sweet Home, Sethe's life as a female slave became worse. The scene that she was raped by the Schoolteacher's nephews directly made her husband Halle crazy.

For Sethe, the physical abuse is humiliating, but the added emotional pain is devastating. She had no rights to hold a wedding ceremony and was usually examined by the Schoolteacher as an animal, thus making her doubt herself whether she was qualified as a human being. The moment when she was raped, she cared more about her body milk being stolen rather than being raped. Sethe couldn't set free herself from the experience and she deemed that she couldn't escape her slave owners. So she lifted a handsaw to kill her baby girl rather than try to drive away the slave catchers. Maybe at that time, it was the best way for her to protect the children from slavery.

To discuss Sethe, her identity as a mother and daughter must be taken into 
consideration at the same time. On the one hand, as a daughter who knew little of her mother, after all those physical, emotional, sexual and spiritual trauma she endured as a slave at Sweet Home, she had borne all of the child's vulnerability and sensitiveness. On the other hand, as a mother who spared no efforts to protect her children, she tried to kill all of her children when slave catchers arrived just in case that they may suffer the huge pains more brutal than death if they had been brought back to the Sweet Home.

There is no denying that it is terrifying when a mother wants to kill her children, however; tracing to the source, it is the slavery system which kills Sethe's baby girl. To say the least, if Sethe took no action as such when Schoolteacher came, she and her four children would all be taken back to the Sweet Home. Then the vicious circle of being abused, raped and sold out would begin again. Sethe would never ever allow her children have the same experience as her out of her traumatic experience as a daughter and mother. Therefore, Sethe's double identities in the maternal love also contribute to the behavior of infanticide.

\subsection{The Female Subjectivity of Baby Suggs and Denver}

The female subjectivity of Baby Suggs is rather strong in the cruel environment. After sixty years as a slave, she still retained a little hope about the future life as a free person. Baby Suggs had spent sixty years as a slave in different plantations in the south, and her last service was in the Sweet Home. She had given birth to eight children, while four were taken and four chased. After her son Halle bought her freedom, she resided in Cincinnati and held gatherings at a place called the Clearing, where she taught her followers to love voices, bodies and minds. However, after Sethe's behavior of infanticide, Baby Suggs broke down physically and emotionally. She stopped preaching and admitted her miserable fate as a slave.

She once praised her son Halle, “A man ain't nothing but a man. But a son? Well now, that's somebody." (Morrison, 1987). Therefore, we can safely conclude that formerly Baby Suggs can recognize her identity as a mother who owns a finial son. It is this identity which gives her confidence and meanings to live in the world. She even has another identity as a preacher in Cincinnati. But her realization as the female subjectivity is too weak to be destroyed, and she has to retreat to a sickbed to die. In Baby Suggs's life, she always lives in terror, and her hope is easily evaporated by slavery, while her pursuit for self-love and identity has great influence on her descendants.

As the third generation, Denver is the loneliest one, but she still demonstrates her self-awareness of the female subjectivity through her brave performance. Denver is Sethe's youngest child who had been stunted in her emotional growth by years of relative isolation. Since childhood, she had sought privacy and repose in the "emerald closet"-a bower formed by a ring of boxwood bushes. At the beginning, Denver was still afraid of her mother Sethe in her deep minds. There is a part of Denver's monologue in this novel, "I love my mother but I know she 
killed one of her own daughters, and tender as she is with me, I'm scared of her because of it." (Morrison, 1987). Therefore, Denver was delighted to have a companion when Beloved came to the house. Nevertheless, with time going by, when Denver saw how Beloved was literally consuming Sethe and witnessed that Sethe became increasingly obsessed with Beloved, Denver realized her initial thought must be wrong and there was a need of rectification. In the end, to save her own mother Sethe and herself, Denver overcame the fear of the outside and sought help from the community.

Denver hadn't suffered those catastrophic experience like her mother and grandmother, and she can hardly get together well enough with her mother or integrate into the community in the first place. From Denver's experience, it is obvious that the female subjectivity, especially the black female subjectivity, has a long way to go to strive for the same rights with men. The respectable thing is that self-isolated Denver dared to associate with unfamiliar people and started to form her own opinions on things and people around her, which demonstrates her self-awareness of the female subjectivity.

\section{Techniques of Deconstruction Concerned with the Female Subjectivity}

This paper has separately discussed the three heroines as the representative female subjectivity in the chapter above, which lays the foundation for this chapter to make a comprehensive survey on the female subjectivity through techniques of deconstruction. Through figures of speech, we can clearly understand the changes of the female subjectivity's life experiences and intention courses. Through etymology and imageries, we can acknowledge that the patriarchal world and slavery system have broken the balance of men and women, slaves and slave owners, mothers and children.

\subsection{Figures of Speech}

When appreciating the literature from the perspective of deconstruction, the use of figures of speech is often noticed and analyzed. This paper focuses on the analysis of pun and repetition.

Through the use of pun, Toni Morrison reveals that the female subjectivity are supposed to learn to confront with the past if they want to move forward. "Pun is the clever or humorous use of a word that has more than one meaning, or of words that have different meanings but sound the same." (Hornby, 2004). In this novel, the most successful use of pun is manifested by the name "Beloved". Sethe considers Beloved as a name given to her dead baby, but the truth is that at her daughter's funeral, the minister addressed the living (including Sethe) as "Dearly Beloved". So Beloved refers to both Sethe and the dead baby (the living and the dead as a whole). Through the use of pun, readers can have an in-depth understanding of the novel. "On a more general level, Beloved also functions as Sethe's repressed memories, as a personal past." (Sun, 2012). The novel presents us a 
picture that the female subjectivity can draw lessons from the past and embrace a better future.

In this novel, repetition is used to express the female subjectivity's strong feelings. Therefore, it is no wonder that the use of repetition is common in the narrative novel. For example, when Sethe expresses her love to the dead girl, she says "Nobody was going to nurse her like me. Nobody was going to get it to her fast enough...Nobody knew that she couldn't pass her air if you held her up on your shoulder...Nobody knew that but me and nobody had her mild but me." (Morrison, 1987). Sethe repeats the word "nobody" to voice that she is the only one to empathize with her baby girl. However, it also shows her constant unsettling sense of the infanticide and the intense denying of her past crime. To recover from the past slavery nightmare, Sethe is bound to be faced with the past and admits her guilt, thus living a better life as the female subjectivity.

\subsection{Etymology}

"Etymology is the study of the history of words, their origins, and how their form and meaning have changed over time." (Hornby, 2004). As a result, we can have a better understanding of the female subjectivity through the analysis of etymology in this novel.

Taking Sethe as an example, in the etymological sense, the name Sethe alludes to Adam and Eve's third son Seth in the Holy Bible, in which Seth is a gift given by God as the substitute of their first son Cain due to that their second son Abel murdered his brother Cain. Morrison endows this name to Sethe to imply she is a substitute of the murdered people during slavery.

Since Sethe is a substitute of the murdered slaves, she is confronted with a dilemma: whether to keep the traumatic memories and unspeakable past or abandon them to yearn for a reassuring future. Just as the arrival of Seth in the Holy Bible manifests God's benevolence and love, the character Sehte created by Morrison implies an eclectic way for slaves to recover from the past, which is retelling the repressed memories to reestablish the identity. In this novel, the female subjectivity always repress the memories to forget the past, however; this repression and dissociation from the past leads to a fragmentation of the selfhood and a loss of true identity. Baby Suggs, Sethe and Denver all experience the loss of selfhood, which could only be healed by the acceptance of the past.

\subsection{Imageries}

Imagery is the author's use of vivid and descriptive language to deepen the meaning of their literary works. In this novel, Morrison forms powerful imageries to appeal to human senses to deepen the readers' understandings of the female subjectivity. The author tries to analyze the imageries in detail associated with the behaviors of the female subjectivity from the perspective of deconstruction.

Colors symbolize the female subjectivity's fantasies; sometimes they cannot 
take control of their lives, let alone disobey the rules made by the patriarchal world. The entire picture of this novel was dominated by pale, white and red colors, while bright colors can hardly be seen except on Baby Suggs' quilt. There is a paragraph depicting how lifeless Room 124 is, "The walls of the room were slate colored... curtains white, and the dominating feature, the quilt over an iron cot, was made up of scraps of blue serge, black, brown and gray wool-the full range of the dark and the muted that thrift and modesty allowed. In that sober field, two patches of orange looked wild-like life in the raw." (Morrison, 1987).

Baby Suggs had been searching for colors in her remaining days. She holds the view that colors wouldn't hurt people. However, it's the color that really hurts and destroys people. With the black color, Sethe has to bend her knees and endures inhuman torture to earn a living for her children, Denver has to lock her heart to satisfy her mother and struggle with the days of apparent serenity. Colors symbolize the fantasies of the female subjectivity, while the resolution for them to struggle for freedom with men not depends on the insubstantial quest for colors, but the awakening of the female subjectivity. Thus, Denver finally makes up her mind to walk out of the house for the community's shelter, and Sethe admits her self-value in the end.

In the world of Beloved, trees serve primarily as sources of healing, comfort and life. The female subjectivity in this novel are always associated with trees, which retrospectively manifests they are under too many sorrows to pursuit natural shelter. Denver's "emerald closet" of boxwood bushes functions as a place of solitude and repose for her. The beautiful trees of Sweet Home mask the true horror of the plantation in Sethe's memory for she finds her freedom by escaping through a forest. By imagining the scars on Sethe's back as a "chokecherry tree", Amy Denver sublimates a site of trauma and brutality into one of beauty and growth. The female subjectivity can not satisfied with their living conditions, but they still try to find happiness and comfort through the natural condolence.

\section{Findings with Analysis}

With all the analysis above, this paper finds measures to reestablish the female subjectivity under slavery, which can be generally summarized to three points as challenging the totalitarian society, seeking for community shelter and reconstructing the identity.

Generally speaking, the female subjectivity in Beloved have all lost their identities, because mothers cannot bring up their children, and women doubt their values as human beings. The most dangerous effect of slavery is its negative impact on the slaves' selfhood. For instance, Sethe acknowledged herself as goods, and gave up her identity as the individual female subjectivity. Therefore, it is necessary to reconstruct the identity of the female subjectivity. Slaves were told they were subhuman and were traded as commodities whose worth could be valued by dollars. Consequently, the female subjectivity in this novel are very in- 
secure about whether or not they could possibly be treated as a real "individual". To ease the female subjectivity's worries, we must help them figure out who they are and admit their values as human beings.

In addition, Beloved demonstrates the extent to which the female subjectivity need the support of their community in order to survive. When Sethe becomes a part of the Cincinnati community, she begins to develop her selfhood during her twenty-eight days of freedom. Similarly, Denver indeed discovers herself and grows up when she leaves Room 124 and becomes a part of society. At the end of the novel, the black community makes up for its past misbehavior by gathering at Room 124 to collectively exorcise Beloved. By driving Beloved away, the community secures Sethe's and its own identity for release from the past. As for the female subjectivity in this novel, it is the community shelter which protects them against the severe environment. As for the Cincinnati's black community, it is the protecting behavior which consolidates the community.

Last but not least, the female subjectivity spare not efforts to challenge the patriarchal society. Patriarchy is a social system in which males hold primary power and predominate in roles of political leadership, moral authority, social privilege and property control. Despite the reconstruction of the identity and the community shelter, the female subjectivity can still hardly be reestablished if the society remains as a patriarchal society. Sethe kills her own daughter to protect her children from the destruction wrought by slavery and patriarchy. Denver exiles from the place named Room 124 and searches for independence and selfpossession. They struggle to free themselves from patriarchy, some succeed while others fail. Those who fail may be too fragile in their inner hearts and indulge themselves in their own world, thus giving up themselves even when opportunities come. Those who succeed always have a thorough understanding of themselves and tend to unite together, so that they can make a breakthrough even in the patriarchal society.

\section{Conclusion}

This paper analyzes the female subjectivity from the perspective of J. Hillis Miller's deconstruction, concretely referring to three aspects-figures of speech, etymology and imageries, which reveals the significance of maternal love and freedom under slavery. Through figures of speech, we can clearly understand the changes of the female subjectivity's life experiences and intention courses. Through etymology and imageries, we can acknowledge that the patriarchal world and slavery system have broken the balance of men and women, slaves and slave owners, mothers and children. The growing experiences of the heroines in this novel are still very meaningful to the modern women. In consideration of the unequal rights between men and women today, we can draw lessons from Beloved that the protection of the female subjectivity requires reconstructing the identity, seeking for community shelter and challenging the patriarchal society. 


\section{Conflicts of Interest}

The authors declare no conflicts of interest regarding the publication of this paper.

\section{References}

Elliott, M. J. S. (2000). Postcolonial Experience in a Domestic Context: Commodified Subjectivity in Toni Morrison's Beloved. MELUS, 25, 181-202. https://doi.org/10.2307/468242

Feng, Q. (1992). Philosophical Dictionary (p. 48). Shanghai: Shanghai Dictionary Publications Inc.

Fuller, M. (2002). Woman in the Nineteenth Century (p. 100). New York: Dover Publications Inc.

Hornby, A. S. (2004). Oxford Advanced Learner's English-Chinese Dictionary (6th ed., pp. 581-1393). Oxford: Oxford University Press.

Krumholz, L. (1992). The Ghosts of Slavery: Historical Recovery in Toni Morrison's Beloved. African American Review, 26, 395-408. https://doi.org/10.2307/3041912

Mill, J. (1996). Mill: The Spirit of the Age, On Liberty, The Subjection of Women (p. 118). New York: W. W. Norton \& Company.

Miller, J. H. (2000). Restate Deconstruction (p. 7). Beijing: China Social Sciences Press.

Morrison, T. (1987). Beloved (pp. 19-286). New York: Vintage Books.

Rousseau, J.-J. (2014). The Major Political Writings of Jean-Jacques Rousseau: The Two Discourses and the Social Contract (2nd ed., p. 219). Chicago, IL: University of Chicago Press.

Sun, Y.-F. (2012). On the Art of Rhetoric in Morrison's Fiction (p. 83). Kunming: Yunnan University Press.

Wollstonecraft, M. (2015). A Vindication of the Rights of Woman (p. 48). New York: Vintage Classics.

Wyatt, J. (1993) Giving Body to the Word: The Maternal Symbolic in Toni Morrison's Beloved. PMLA, 108, 474-488. https://doi.org/10.2307/462616 